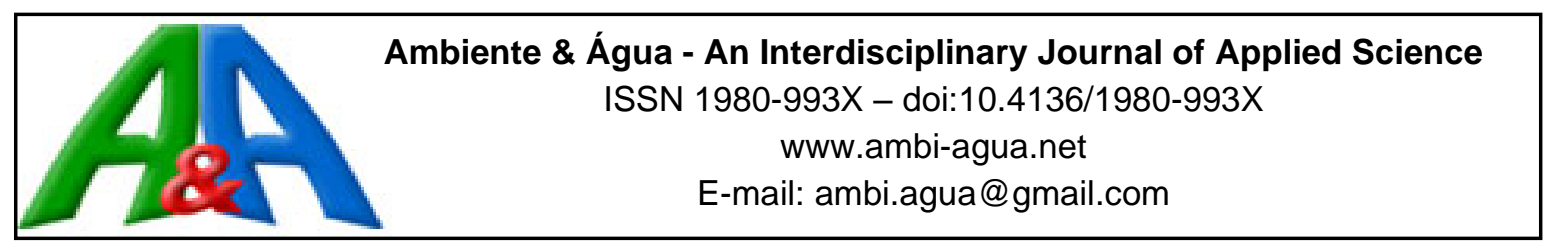

\title{
Spatial and temporal variation and the influence of environmental parameters in a fish community in the Una River, Paraíba do Sul Valley, São Paulo
}

\author{
ARTICLES doi:10.4136/ambi-agua.2539
}

Received: 21 Sep. 2020; Accepted: 17 Oct. 2020

\author{
Juliano Rodrigues Honorio*iD; Itamar Alves Martins \\ Programa de Pós-Graduação em Ciências Ambientais (PPGCA). Universidade de Taubaté (UNITAU), \\ Estrada Municipal Doutor José Luiz Cembranelli, n5000, CEP: 12081-010, Taubaté, SP, Brazil. \\ E-mail: itamarmartins1@gmail.com \\ *Corresponding author. E-mail: julianorh0022@gmail.com
}

\begin{abstract}
Understanding of aspects of the structure of ichthyological communities and how these relate to the environment and its natural variation has been one of the principal objectives of ecological studies conducted in freshwater environments. The objective of this study was to evaluate the relationship between fish species composition in the Una River and environmental variables during dry and rainy seasons. Data collection was done along three stretches of the main channel of the Una River between April 2016 and March 2017. In general, the riverbed presented a high degree of silting in all study sites. A total of 1,534 fish specimens from thirty species were collected. There was greater richness and abundance of species during the rainy season in all sampled areas. A Partial Redundancy Analysis (pRDA) showed a significant correlation between the fish community, substrate composition, and concentrations of dissolved oxygen in the water. The qualitative structure of the ichthyofauna indicated a greater association with environmental structure than with seasonality, since there was a clear tendency for the three stretches of river to group together independent of the sampling period. There were no significant differences between the indices of diversity registered for the dry and rainy seasons. This is due to the dominance of the species Astyanax aff. bimaculatus (two spot Astyanax | lambari-do-rabo-amarelo) and Hypostomus cf. luetkeni (armoured catfish | cascudo), which represented more than half of the collected specimens during the rainy season.
\end{abstract}

Keywords: bioindicators, ichthyofauna, Paraíba do Sul river watershed, seasonality.

\section{Variação espaço-temporal e influência de parâmetros ambientais na comunidade de peixes do rio Una, Vale do Paraíba do Sul, São Paulo}

\section{RESUMO}

O entendimento dos fatores estruturadores das comunidades ictiológicas e como estas se relacionam com o ambiente e suas variações têm sido considerado um dos principais objetivos no estudo em ecologia de ambientes dulcícolas. O objetivo do presente estudo foi avaliar a relação entre a composição de espécies de peixes do rio Una e variáveis ambientais ao longo dos períodos seco e chuvoso. As coletas foram realizadas em três trechos ao longo do canal principal do rio Una, no período de abril de 2016 a março de 2017. No geral, o leito do rio 
apresentou acentuado grau de assoreamento em todos os trechos estudados. Foi coletado um total de 1.534 exemplares de peixes, pertencentes a trinta espécies. Durante o período chuvoso registrou-se maior riqueza e abundância de espécies em todos os trechos amostrados. A análise de Redundância Parcial (pRDA) mostrou uma correlação significativa entre a comunidade de peixes e a composição do substrato e taxas de oxigênio dissolvido na água. A estrutura qualitativa da ictiofauna indicou maior associação com a estrutura ambiental do que com a sazonalidade, visto a tendência dos trechos se agruparem independentemente do período amostrado. Não houve diferenças significativas entre os índices de diversidade registrados durante os períodos seco e chuvoso. Isso se deve ao fato da dominância das espécies Astyanax aff. bimaculatus (lambari-do-rabo-amarelo) e Hypostomus cf. luetkeni (cascudo) que corresponderam a mais da metade dos exemplares coletados durante o período chuvoso.

Palavras-chave: bacia do rio Paraíba do Sul, bioindicadores, ictiofauna, sazonalidade.

\section{INTRODUCTION}

Understanding of structural factors of ichthyological communities and how these relate to the environment and its natural variation has been one of the principal objectives of ecological studies conducted in freshwater environments (Giller and Malmqvist, 1998). Habitat structure and temporal changes in environmental conditions are recognized as being able to influence patterns of fish species composition and distribution, especially in small rivers and streams where species are highly dependent on structural components of the aquatic environment for survival (Poff, 1997; Allan, 2004; Kovalenko et al., 2012).

The importance of physical and limnological characteristics of the environment as predictors of fish community structure has been established in current ecological literature, and a large diversity of functions are recognized (Ferreira et al., 2014; Gonçalves et al., 2018). Trunks, branches, and leaves increase structural complexity of bodies of water as these serve as refuge from predators, shelter from strong currents, places for egg deposition and development of juvenile fish, besides providing a variety of food sources (Angermeier and Karr, 1984; Crook and Robertson, 1999; Casatti et al., 2012; 2015). Limnological characteristics, such as water temperature, $\mathrm{pH}$, and levels of dissolved oxygen exert great influence on distribution of fish species due to their particular physiological characteristics (Angermeier and Karr, 1984; Pulsey and Arthington, 2003; Allan and Castillo, 2007; Ferreira et al., 2014).

Structural and limnological environmental factors are therefore subject to fluctuations caused by seasonal variation in hydrological cycles, a common characteristic of tropical rivers (Lowe-McConnell, 1987; Junk et al., 1989; Correa and Winemiller, 2014). Such changes tend to influence the structure and composition of local assemblages through habitat availability and ecosystem productivity, thus establishing connections between bodies of water in adjacent areas during the period of greater rainfall, or conversely, isolating these habitats during dry periods (Power et al., 2008; Jardine et al., 2015; Fitzgerald et al., 2017; Sabo et al., 2017).

In this context, the Una River and its basin is one of the most important tributaries of the Paraíba do Sul watershed in the state of São Paulo. This basin has been suffering intense anthropogenic activity throughout its drainage area, which has severely changed its natural environmental conditions (Batista et al., 2005; Targa, 2009). Currently, there is little information on the ichthyofauna of the Una River Basin, with the study by Honorio and Martins (2018) being the only one to address the question of fish species in this region, which demonstrates the necessity for new studies, especially with respect to biology of species. Therefore, the objective of this study was to evaluate the relationship between fish species composition in the main channel of the Una River and environmental variables during dry and rainy seasons in order to support the implementation of future strategies for environmental recuperation and protection of fauna in this basin. 


\section{MATERIAL AND METHODS}

\subsection{Study area}

The Una River Basin is located in the region of the Paraíba do Sul Valley in the state of São Paulo and has an area of $476 \mathrm{~km}^{2}$ which are mostly within the municipality of Taubaté (84\%). It also drains the municipalities of Redenção da Serra, Pindamonhangaba and Tremembé (Batista et al., 2005). The Una River is formed by the confluence of the Santa Luzia River and the Almas Brook in the municipality of Taubate, flowing a distance of $36 \mathrm{~km}$ until its confluence with the Paraíba do Sul River in the municipality of Tremembé (Prado and Abreu, 1995).

Altitude within the Una River Basin varies between 500 and 900 meters, and the limits of the basin are the Quebra-Cangalha Mountains to the northeast, and the Jambeiro Mountains to the southeast. The topography of the basin is strongly undulating in the upper portion, which becomes flatter in the lower course of the main channel (Prado and Abreu, 1995).

The natural vegetation of the Una River Basin is typical of the Atlantic Rainforest, which is currently restricted only to the higher altitudes in the basin, such as on the slopes of the Mantiqueira Mountains or within private properties in the form of small nature reserves, which therefore make up a mosaic of preserved areas surrounded by hills covered by pastures. There is also a small remnant area of savannah located at the border between the municipalities of Taubaté and Caçapava (Freitas Júnior and Marson, 2007).

The predominant climate in the Una River Basin is subtropical humid with a dry winter with temperatures below $18^{\circ} \mathrm{C}$, and a hot summer, with average temperatures above $22^{\circ} \mathrm{C}$ (Devide et al., 2014). In the municipality of Taubaté, in which most of this basin is located, July and August are the driest months, and October through March is the rainy season (DAEE, 2017).

\subsection{Sampling}

Three stretches of the Una River were sampled monthly between April 2016 and March 2017. Stretch A1 $\left(23^{\circ} 05^{\prime} 03.7^{\prime \prime} \mathrm{S}-45^{\circ} 29^{\prime} 00.5^{\prime} \mathrm{W}\right)$, was located in the headwaters of the river

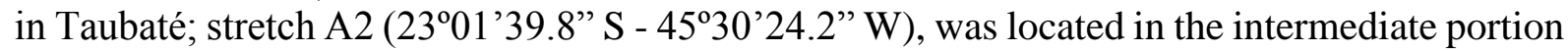
of the river, which drains a floodplain area (várzea); stretch A3 (A3: 22 55'53.5" S 45'31'24.3" W), was situated near the confluence of the Una River with the Paraíba do Sul River in the municipality of Tremembé (Figure 1).

For measurement of environmental variables, 100 meter stretches of river were delimited within each collection area A1 to A3, and before fish collection three structural descriptors were measured (depth, velocity of current, predominant substrate), along with three limnological descriptors ( $\mathrm{pH}$, dissolved oxygen, water temperature).

A standardized method was used for collection of fish specimens which consisted of use of a casting net with a $0.5 \mathrm{~mm}$ mesh between opposing knots, dip nets (puçás), and manual drag nets with a $0.1 \mathrm{~mm}$ mesh between opposing knots. The collected specimens were fixed in a $10 \%$ formalin solution and then transferred to a solution of $70 \%$ ethanol. All collected individuals were deposited in the Coleção Científica do Laboratório de Zoologia da Universidade de Taubaté - CCLZU / UNITAU.

\subsection{Data analysis}

The ecological descriptors of the fish assemblages were determined by applying the Shannon-Wiener diversity index (H'), which attributed greater weight to rare species, and the Simpson dominance index (D), which reflects the degree of dominance in the community, attributing greater weight to common species. Equitability was calculated using the Pielou (J) index, which indicates the degree of similarity between the abundance of the different species sampled (Magurran and McGill, 2011). 


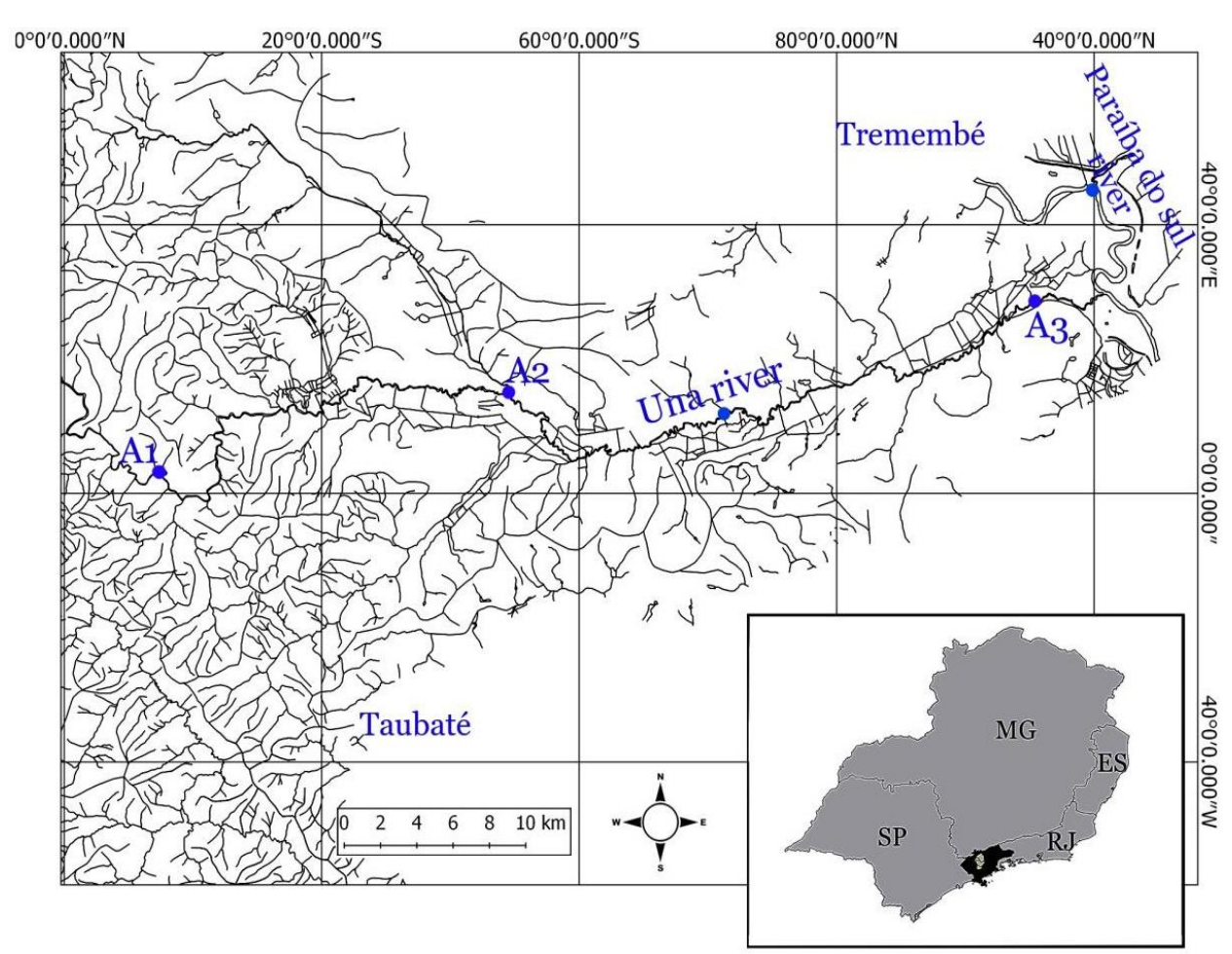

Figure 1. Map of the hydrographic basin of the Una River, Paraíba do Sul River Valley, São Paulo. The three stretches of the main channel of the Una River that were sampled are highlighted. A1: $23^{\circ} 05^{\prime} 03.7^{\prime \prime} \mathrm{S}-45^{\circ} 29^{\prime} 00.5^{\prime \prime} \mathrm{W}$; A2:

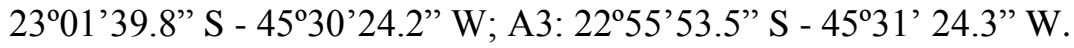

The influence of seasonality on species composition was evaluated using a t-test, as proposed by Hutchenson (1970), which compared the values of the Shannon-Wiener index from the three stretches of river during the dry and rainy seasons. Additionally, in order to evaluate the qualitative structure of the ichthyofauna in the three stretches of river during the dry and rainy seasons, a similarity dendrogram was constructed using the Jaccard coefficient and the Unweighted Pair Group Method with Arithmetic Mean (UPGMA) in the Biodiversity PRO statistical program.

The effects of environmental parameters on species composition in the community were evaluated using the Partial Redundancy Analysis (pRDA) in the R statistical program. For this, a matrix of the species was transformed using the Hellinger transformation in order to apply linear methods to these data, such as the pRDA (Peres-Neto et al., 2006). To remove the influence of extreme values, velocity of current, depth, water temperature, and dissolved oxygen were log-transformed (Borcard et al., 2011). Qualitative measurements such as substrate type were transformed into quantitative indices which were calculated using weighted averages (Gonçalves and Braga, 2012).

\section{RESULTS AND DISCUSSION}

\subsection{Environmental parameters}

With respect to the environmental parameters evaluated in this study, each sampled stretch of the river demonstrated its own unique characteristics in terms of substrate composition, depth, and current velocity. The stretch A1 is characterized as shallow, having a relatively fast current, with a diverse substrate composition. The stretch A2 had slow, deep waters with little dissolved oxygen, besides a substrate predominantly composed of sand. The stretch A3 was the most diversified in relation to substrate composition and had the highest current velocity (Table $1)$. 
Table 1. Average, standard deviation (DP) and amplitude (in parentheses) of the environmental indicators registered in the three sampled stretches of the Una River during the dry and rainy (wet) seasons.

\begin{tabular}{|c|c|c|c|c|c|c|}
\hline \multirow[b]{2}{*}{ Variables } & \multicolumn{2}{|c|}{ stretch A1 } & \multicolumn{2}{|c|}{ stretch A2 } & \multicolumn{2}{|c|}{ stretch A3 } \\
\hline & Dry & Wet & Dry & Wet & Dry & Wet \\
\hline Water temperature $\left({ }^{\circ} \mathrm{C}\right)$ & $\begin{array}{c}20.18 \pm \text { DP } 3.47 \\
\quad(15.1-25.2)\end{array}$ & $\begin{array}{c}21.7 \pm \text { DP } 3.40 \\
(21.4-29.3)\end{array}$ & $\begin{array}{c}19.81 \pm \text { DP } 5.33 \\
(10.5-26.1)\end{array}$ & $\begin{array}{c}26.95 \pm \text { DP } 1.09 \\
(25.1-28.2)\end{array}$ & $\begin{array}{c}20.85 \pm \text { DP } 3.67 \\
(17.2-26.4)\end{array}$ & $\begin{array}{c}26.15 \pm \text { DP } 1.24 \\
\quad(24.5-27.4)\end{array}$ \\
\hline $\mathrm{pH}$ & $\begin{array}{c}7.48 \pm \text { DP } 0.21 \\
(7.1-7.7)\end{array}$ & $\begin{array}{c}7.41 \pm \text { DP } 0.21 \\
(7.2-7.8)\end{array}$ & $\begin{array}{l}7.45 \pm \text { DP } 0.57 \\
\quad(6.2-7.08)\end{array}$ & $\begin{array}{c}7.3 \pm \text { DP } 0.13 \\
(7.3-7.7)\end{array}$ & $\begin{array}{c}7.46 \pm \text { DP } 0.18 \\
(7.2-7.6)\end{array}$ & $\begin{array}{c}7.43 \pm \text { DP } 0.42 \\
(6.7-7.9)\end{array}$ \\
\hline Dissolved oxygen & $\begin{array}{c}7.96 \pm \text { DP0.46 } \\
(7.71-8.99)\end{array}$ & $\begin{array}{l}8.42 \pm \text { DP0.74 } \\
(7.01-8.76)\end{array}$ & $\begin{array}{l}8.42 \pm \text { DP } 0.91 \\
\quad(4.33-6.56)\end{array}$ & $\begin{array}{c}5.48 \pm \text { DP } 1.67 \\
(3.49-6.79)\end{array}$ & $\begin{array}{c}7.1 \pm \text { DP } 0.62 \\
(7.45-8.87)\end{array}$ & $\begin{array}{c}8.21 \pm \text { DP } 0.90 \\
(5.48-7.95)\end{array}$ \\
\hline Depth & $\begin{array}{c}0.9 \pm \text { DP } 2.97 \\
(0.52-0.8)\end{array}$ & $\begin{array}{c}1.03 \pm \text { DP } 0.22 \\
(0.59-1.07)\end{array}$ & $\begin{array}{c}0.88 \pm \text { DP } 0.13 \\
(0.68-1.09)\end{array}$ & $\begin{array}{l}0.98 \pm \text { DP } 0.26 \\
(0.72-1.38)\end{array}$ & $\begin{array}{c}0,75 \pm \text { DP } 0.30 \\
(0.43-1.13)\end{array}$ & $\begin{array}{c}0.78 \pm \text { DP } 0.26 \\
(0.51-1.15)\end{array}$ \\
\hline Current velocity $(\mathrm{m} / \mathrm{s})$ & $\begin{array}{c}0.71 \pm \mathrm{DP} 0.24 \\
(0.5-1.0)\end{array}$ & $\begin{array}{c}0.94 \pm \text { DP0.48 } \\
(0.5-1.44)\end{array}$ & $\begin{array}{c}0.66 \pm \text { DP } 0.04 \\
(0.59-0.63)\end{array}$ & $\begin{array}{c}0.72 \pm \text { DP } 0.05) \\
(0.67-0.8)\end{array}$ & $\begin{array}{c}1.26 \pm \text { DP } 0.47) \\
(0.75-1.73)\end{array}$ & $\begin{array}{c}1.09 \pm \text { DP } 0.44 \\
(0.70-1.75)\end{array}$ \\
\hline
\end{tabular}

\section{Substrate}

clay, sand, shale and rock

clay and sand

clay, sand, gravel, shale and rock

The concentrations of dissolved oxygen were lower during the rainy season when compared to those registered during the dry season in A2. In the other stretches of river sampled the inverse occurred, with higher concentrations of dissolved oxygen during the rainy season. These differences were statistically significant for all the studied stretches. The $\mathrm{pH}$ values were, in general, lower during the dry season, and these differences were statistically significant only for A2.

The evaluated environmental parameters explained $32.5 \%$ of the total variation in community composition. The first two axes of the RDA were responsible for $82.4 \%$ of the explained variation. With respect to environmental predictors, community composition was statistically correlated with substrate composition $(\mathrm{p}<0.001)$ and dissolved oxygen $(\mathrm{p}<0.0100)$ (Figure 2$)$. 


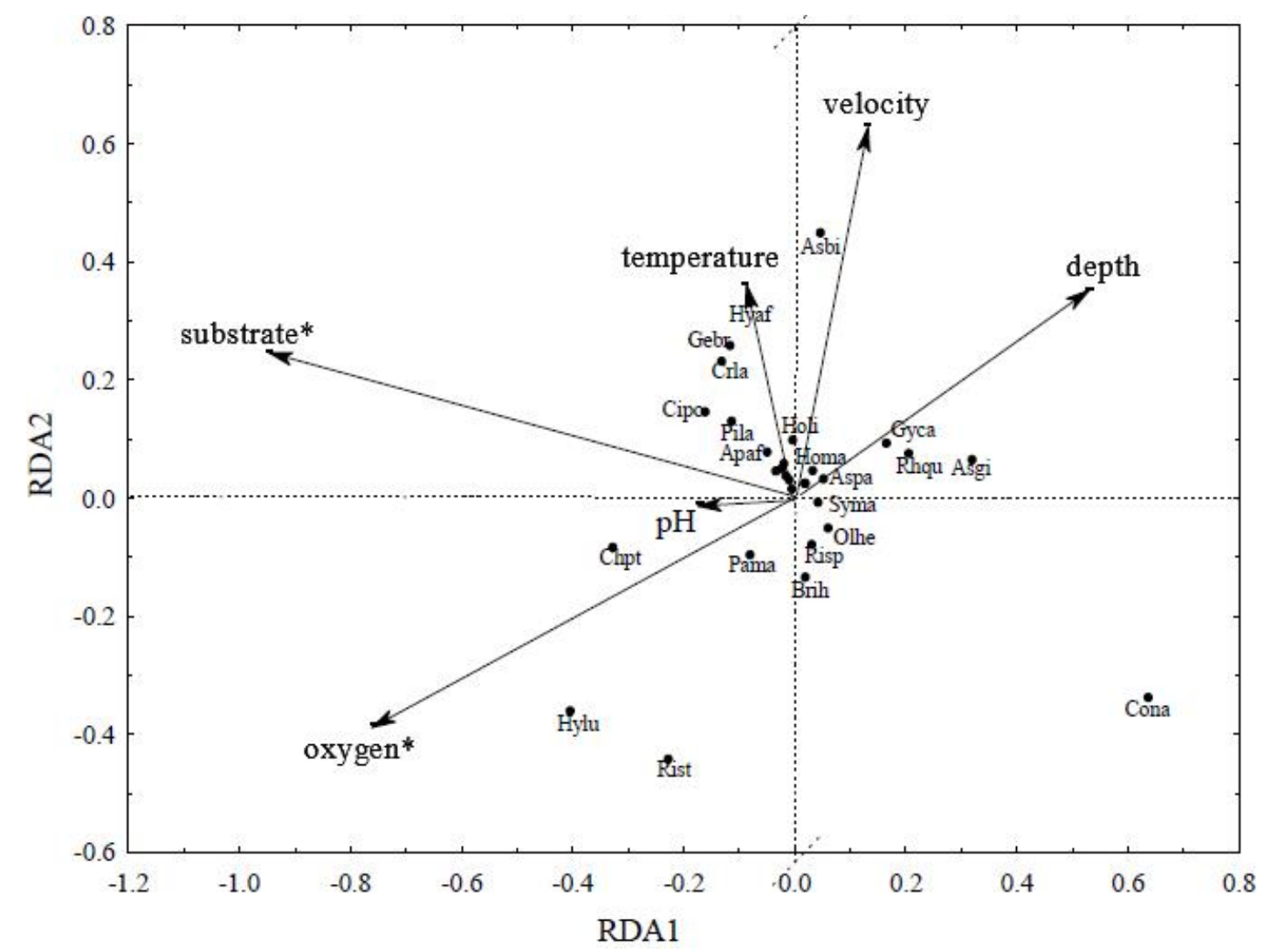

Figure 2. Results from the Partial Redundancy Analysis (pRDA) showing the pattern of correlations between species abundance and the evaluated environmental parameters. The asterisks indicate the variables that are statistically correlated $(\mathrm{p} \leq 0.05)$ with community composition. Species are identified by their abbreviations.

\subsection{Ichthyofauna}

A total of 1,069 individuals (69.4\%) were captured during the rainy season, and 469 individuals (30.6\%) during the dry season, and ten species were registered only during the rainy season. The variation in species abundance in each stretch showed a non-significant tendency to increase during the rainy season in the three sampled stretches of river $(p>0.13)$. The analyses of the diversity indices $\left(H^{\prime}\right)$ showed no significant differences for seasonality for any of the sampled sites $(\mathrm{p}>0.31)$ (Table 2).

The qualitative structure of the ichthyofauna indicated little influence of seasonality on species composition. The similarity analysis grouped the samples together independent of the sampling period, except for A1, whose species composition was similar to A3 during the dry season, and A2 during the rainy season (Figure 3).

\subsection{Discussion}

With respect to the general characteristics of the sampled stretches of river, it is important to emphasize the poor conditions of environmental preservation of the Una River as a whole. Even the stretches that were more heterogeneous in substrate composition had a large accumulation of sediment in the canal and along the margins. This is probably due to the absence of vegetation cover along the river margins, which is principally caused by the use of adjacent lands for agricultural and cattle ranching activities and timber harvesting. This scenario is corroborated by previous studies done in the Una River Basin, which found that the substitution of native vegetation by pastures was one of the main environmental problems in the basin and the cause of silting of the river canal. This silting is responsible for the constant flooding of roads and floodplain areas in the middle to lower stretches of the Una River in the municipality of Taubaté (Batista et al., 2005; Targa, 2009). 
Table 2. Absolute abundance and richness of collected species in the three sampled stretches during the dry and rainy (wet) seasons. Diversity metrics: Indices of ShannonWiener (H'), Simpson (D), and equitability (J). Comparison between the diversity indices $\left(\mathrm{H}^{\prime}\right)$ obtained during the dry and rainy seasons in each stretch of river $(\mathrm{p})$. Species abbreviations in parentheses.

\begin{tabular}{|c|c|c|c|c|c|c|}
\hline \multirow[b]{3}{*}{ Species } & \multicolumn{6}{|c|}{ Sampling stretches } \\
\hline & \multicolumn{2}{|c|}{ A1 } & \multicolumn{2}{|c|}{$\mathbf{A 2}$} & \multicolumn{2}{|c|}{ A3 } \\
\hline & Dry & Wet & Dry & Wet & Dry & Wet \\
\hline Apareiodon affinis (Apaf) & - & - & - & - & - & 7 \\
\hline Prochilodus lineatus (Prli) & - & - & - & 1 & - & - \\
\hline Characidium pterostictum (Chpt) & 14 & 9 & - & - & 10 & 8 \\
\hline Astyanax aff. bimaculatus (Asbi) & 28 & 89 & 43 & 93 & 79 & 242 \\
\hline Astyanax giton (Asgi) & - & 1 & 6 & 12 & - & - \\
\hline Astyanax parahybae (Aspa) & - & - & 1 & 1 & - & - \\
\hline Bryconamericus iheringii (Brih) & 7 & 11 & 9 & 11 & 15 & 19 \\
\hline Hyphessobrycon eques (Hyeq) & - & - & - & - & - & 1 \\
\hline Oligosarcus hepsetus (Olhe) & 1 & - & 1 & 4 & - & 2 \\
\hline Metynnis sp. (Mesp) & - & - & - & - & - & 2 \\
\hline Hoplias malabaricus (Homa) & - & 2 & 2 & 1 & & \\
\hline Trichomycterus albinotatus (Tral) & - & 4 & - & - & - & - \\
\hline Corydoras nattereri (Cona) & - & 2 & 99 & 24 & 2 & 5 \\
\hline Hoplosternum littorale (Holi) & 1 & - & - & 2 & - & 6 \\
\hline Ancistrus multispinis (Asmu) & - & - & - & - & - & 2 \\
\hline Hypostomus affinis (Hyaf) & 1 & 2 & - & 13 & 3 & 40 \\
\hline Hypostomus cf. luetkeni (Hylu) & 25 & 84 & 4 & 9 & 14 & 57 \\
\hline Parotocinclus maculicauda (Pama) & 2 & 10 & - & 1 & - & 1 \\
\hline Rineloricaria cf. steindachneri (Rist) & 22 & 46 & 4 & 7 & 2 & 9 \\
\hline Rineloricaria sp. (Risp) & - & - & - & 2 & - & - \\
\hline Pimelodella lateristriga (Pila) & 6 & 50 & 7 & 9 & 15 & 37 \\
\hline Rhamdia quelen (Rhqu) & - & 1 & 5 & 4 & - & - \\
\hline Pimelodus maculatus (Pima) & - & - & - & - & 1 & 2 \\
\hline Glanidium melanopterum (Glme) & - & 1 & - & - & - & - \\
\hline Gymnotus carapo (Gyca) & 1 & 5 & 4 & 6 & - & - \\
\hline Synbranchus marmoratus (Syma) & - & - & - & 3 & - & - \\
\hline Cichlasoma portalegrense (Cipo) & 2 & 1 & 2 & 4 & 9 & 49 \\
\hline Crenicichla lacustris (Crla) & - & - & - & - & 5 & 18 \\
\hline Geophagus brasiliensis (Gebr) & - & 1 & - & 10 & 14 & 22 \\
\hline Oreochromis niloticus (Orni) & - & - & - & 1 & - & - \\
\hline Richness & 12 & 17 & 13 & 21 & 13 & 19 \\
\hline Absolute richness & \multicolumn{2}{|c|}{19} & \multicolumn{2}{|c|}{21} & \multicolumn{2}{|c|}{20} \\
\hline Abundance & 110 & 319 & 187 & 218 & 171 & 529 \\
\hline Total abundance & \multicolumn{2}{|c|}{429} & \multicolumn{2}{|c|}{405} & \multicolumn{2}{|c|}{700} \\
\hline Shannon-Wiener index (H') & \multicolumn{2}{|c|}{1.958} & \multicolumn{2}{|c|}{2.042} & \multicolumn{2}{|c|}{1.974} \\
\hline Simpson index (D) & \multicolumn{2}{|c|}{0.813} & \multicolumn{2}{|c|}{0.783} & \multicolumn{2}{|c|}{0.755} \\
\hline Equitability (J) & \multicolumn{2}{|c|}{0.664} & \multicolumn{2}{|c|}{0.67} & \multicolumn{2}{|c|}{0.658} \\
\hline $\mathrm{p}$ (t-test Hutchenson) & \multicolumn{2}{|c|}{0.89} & \multicolumn{2}{|c|}{1.62} & \multicolumn{2}{|c|}{0.31} \\
\hline
\end{tabular}




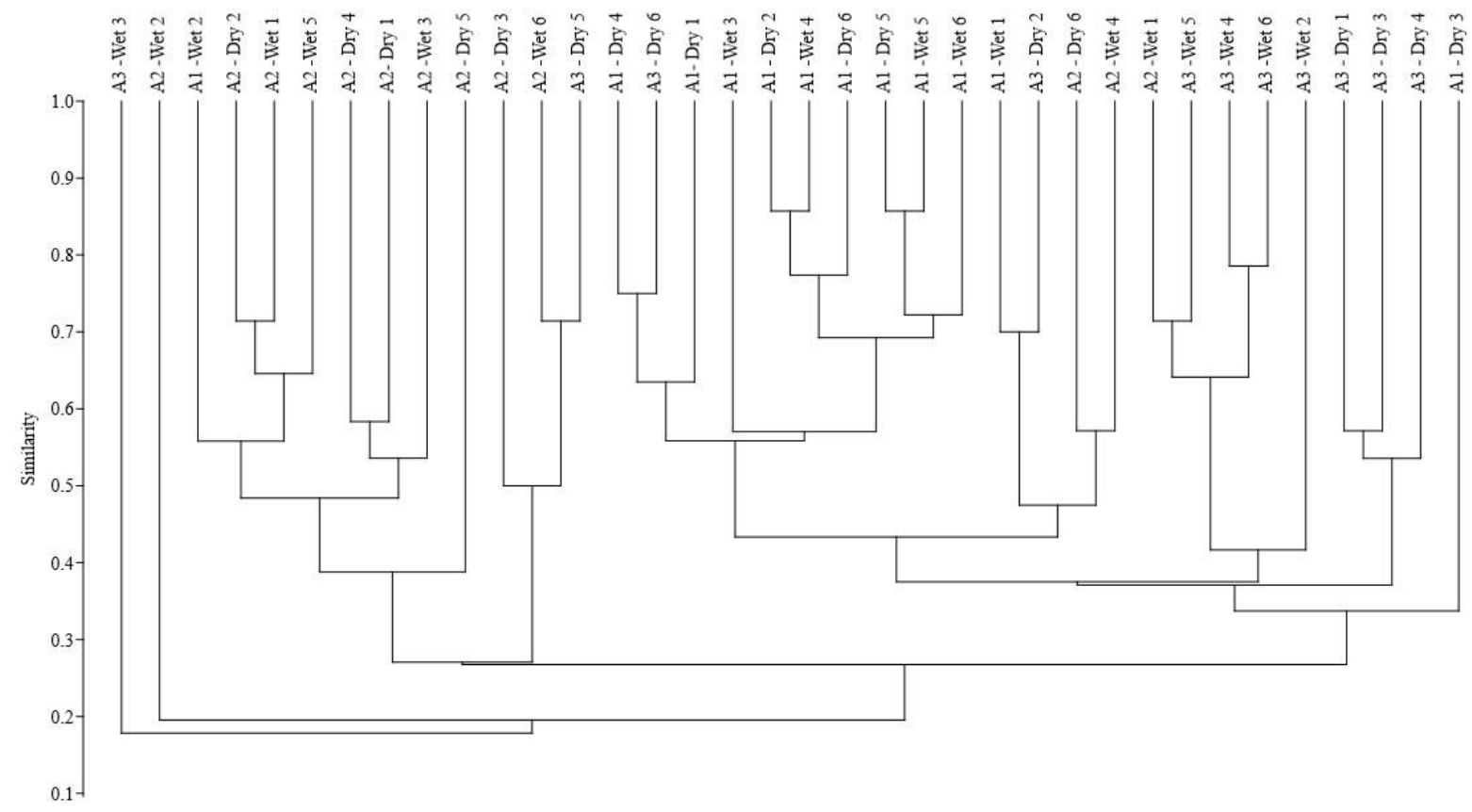

Figure 3. Similarity dendrogram using the Jaccard coefficient and the Unweighted Pair Group Method with Arithmetic Mean (UPGMA) for the sampled stretches of river.

The values for $\mathrm{pH}$ and dissolved oxygen reported in this study are within the range observed for the Paraíba do Sul River and its tributaries, whose waters vary between neutral to slightly alkaline (Figueiredo et al., 2011). The lower values of dissolved oxygen in A2 during the rainy season can be explained by the fact that oxygen solubility in water is directly linked to temperature variation, so that as temperature increases the rate of release of this gas to the atmosphere will also increase in the respiration rate of aquatic organisms, which tends to increase with temperature (Esteves, 1998; Souza et al., 2010; Gomes et al., 2013). For the stretches $\mathrm{A} 1$ and $\mathrm{A} 3$, where the inverse of this relationship was observed, the greater concentration of dissolved oxygen during the rainy season can be explained by the greater volume of water and subsequent increase in the velocity of the current, since one of the mechanisms of fixation of oxygen in water occurs through physical processes, which are enabled by an increase in the velocity of the current (Krupek et al., 2008).

The Partial Redundancy Analysis (pRDA) showed a significant influence on the concentration of dissolved oxygen on the variation in species composition. The ordination graph (Figure 2) indicates a positive association between this variable and the species Characidium pterostictum and Parotocinclus maculicauda, restricted to the stretches A1 and A3, which are characterized by fast currents and oxygenated water, besides a substrate composed of rocks and gravel. However, this result may be more associated with structural composition of the habitat than with the availability of oxygen dissolved in the water. For example, Characidium pterostictum and $P$. maculicauda are known to inhabit aquatic environments with rapid water and rocky substrate, where they predominantly feed on organic matter that adheres to hard substrate such as trunks and rocks, besides particles in suspension carried by the current (Buckup and Reis, 1997; Leitão et al., 2007; Leitão and Buckup, 2014; Leitão et al., 2015).

Some species may be considered indicators of specific environmental conditions in the Una River. For example, the stretch A2 had a relatively high diversity and abundance of species tolerant to hypoxic conditions. Callichthyidae (Corydoras nattereri and Hoplosternum littorale) and Gymnotidae (Gymnotus carapo) were constantly captured in this stretch where the lowest dissolved oxygen concentrations were recorded. These species use obligate accessory aerobic respiration which allows them to inhabit environments that are practically 
anoxic, where few species are able to survive (Crampton, 1996; Reis, 2003). Waters with low oxygen levels indicate input of organic matter, whose decomposition by bacteria is accompanied by an increase in consumption of oxygen, thereby reducing the amount dissolved in the water (Souza et al., 2010). Limnological studies are necessary to explain the low oxygen levels in this stretch of the river. One of the causes may be that A2 is located near the confluence of the Una River with Itaim Brook, one of the principal tributaries that crosses the rural zone of the municipality of Taubaté and which has a large diversity of animal husbandry activities along its course, besides receiving effluent from a dairy processing cooperative. For these reasons, the low oxygen levels in this stretch of the Una River could be due to its mixing with waters from the Itaim Brook.

The River Continuum Concept formulated by Vannote et al. (1980) predicts a gradual increase in the number of species along a longitudinal gradient because of an increase in the physical and structural complexity of the environment. In the Una River this pattern of longitudinal increase in species was observed. However, this phenomenon does not appear to be related to an increase in the physical and structural complexity of the main channel, since the greatest species diversity was registered at A2, which was characterized as the most structurally simple of the sampled stretches of river.

The fact that A2 is in a floodplain area could be one of the determining factors for the high level of species diversity compared to the stretches at the headwaters and the mouth. Floodplain areas are, in general, highly productive and a rich source of food for fish assemblages (Junk et al., 1989). The connections between lotic environments and floodplain areas tend to be intensified during periods of greater rainfall when the limits of rivers are expanded into adjacent terrestrial areas, thus enabling migration of species from different stretches of a river to occupy new areas created by the increase in water volume (Scholosser, 1982; Langeani et al., 2005; Rezende et al., 2010).

Despite being the most structurally heterogeneous stretch, A3 did not present the highest diversity indicators, which occurred due to the dominance of Astynax aff. bimaculatus, which represented nearly half of the specimens collected in this stretch. This characid composes a group of species that is amply distributed and present in practically all hydrological basins in South America (Lucena and Soares, 2016). Studies done in the Paraíba do Sul Basin relate the wide distribution of this species (Araújo and Nunan, 2005; Teixeira et al., 2004; Araújo et al., 2010). Due to the abundance of specimens collected in the current study, it is possible to infer that this species is also widely distributed in the Una River Basin.

During the rainy season, the greatest species richness and abundance was registered in all sampled river stretches. Similar results have been observed in studies conducted in neotropical environments (Garutti, 1988; Mazzoni and Lobón-Cerviá, 2000, Casatti, 2005; Ferreira and Casatti, 2006). According to Ferreira and Casatti (2006), this increase is generally due to an intensification of the reproductive period, associated or not with recruitment of individuals from adjacent areas. However, the species diversity registered in the Una River was not statistically affected by seasonality, corroborating a pattern described for other lotic tropical systems (Agostinho et al., 2001; 2009). For these authors referenced above, diversity indices during the rainy season tend to be influenced by a high dominance of a few species. During the rainy season, the abundance of $A$. aff. bimaculatus and $H$. cf. luetkeni corresponded to more than half of the total number of individuals collected in the three stretches of river. Furthermore, species found exclusively during this period had a low number of individuals, which had a strong influence on the values of the diversity indices.

The similarity analyses (Figure 3) indicated a greater influence of environmental structure in relation to seasonality on the composition of the ichthyofauna in the Una River. The exception to this was A1, where samples showed a tendency to group together by the stretch of river, independent of sampling period. The variation in species composition in this stretch is 
apparently related to its proximity to the headwaters of the river. In these environments, population dynamics tend to be influenced by the large fluctuations over time in the volume of water (Schlosser, 1982).

\section{CONCLUSIONS}

In synthesis, despite the accentuated degree of environmental degradation, the Una River presents a relatively diverse ichthyofauna (Honorio and Martins, 2018). The composition and distribution of species is more influenced by environmental structure than by seasonality. Future investigations of habitat use by species are needed, along with studies related to the current environmental conditions, in order to measure the impacts from anthropogenic actions on biological communities.

\section{ACKNOWLEDGEMENTS}

The authors thank Antônio Teotonio Honorio, Neide Aparecida Honorio and Marlene Marta da Silva Honorio for their help with fieldwork. We also thank Francisco Langeani Neto (DZSJRP) for the valuable help with species identification, and Eduardo Henrique Teixeira (CCLZ/UNITAU) and Roselene Silva Costa Ferreira (DZSJRP) for laboratory work. Special thanks are given to the Graduate Program in Environmental Sciences (PPGCA/UNITAU), and FAPETI (Foundation for Support of Research, Technology, and Innovation) for funding for this research.

\section{REFERENCES}

AGOSTINHO, A. A.; GOMES, L. C.; ZALEWSKI, M. The importance of floodplains for the dynamics of fish communities of the upper river Paraná. Ecohydrology and Hydrobiology, v 1, n 1-2, p. 209-217, 2001.

AGOStinho, A. A.; PELICICE, F. M.; MARQUES, E. E. Reservatório de Peixe Angical: bases ecológicas para o manejo da ictiofauna. São Carlos, RiMa, 2009. 188 p.

ALLAN, J. D.; CASTILLO, M. M. Stream Ecology: Structure and Function of Running Waters. 2nd ed. New York: Chapman and Hall, 2007. 436 p.

ALLAN, J. D. Landscapes and riverscapes: the influence of land use on stream ecosystems. Annual Review of Ecology, Evolution, and Systematics, v. 35, p. 257-284. 2004.

ANGERMEIER, P. L.; KARR, J. R. Fish communities along environmental gradients in a system of tropical streams. In: ZARET, T. M. (ed.). Evolutionary ecology of neotropical freshwater fishes. The Hague: Springer, 1984. p. 39-57. https://doi.org/10.1007/BF00690857

ARAÚJO, J. R. S.; MOURA, W. O. R.; NUNAN, G. W. Avaliação Ambiental do rio Paraíba do Sul: Trecho Funil-Santa Cecília. Rio de Janeiro: INEA, 2010. 132 p.

ARAÚJO, J. R. S.; NUNAN, G. W. Ictiofauna do rio Paraíba do Sul: Danos Ambientais e sociais causados por barragens, hidrelétricas e poluição no trecho fluminense. Rio de Janeiro: CPDMA-ALERJ, 2005. 59 p.

BATISTA, G. T.; TARGA, M. S.; FIDALGO, E. C. C. Banco de dados ambientais da Bacia do Rio Una, Bacia do Rio Paraíba do Sul. 2005. Available at: http://www.agro.unitau.br/una/. Access: 14 June 2017. 
BORCARD, D.; GILlET, F.; LEGENDRE, P. Numerical Ecology with R. New York: Springer, 2011.302 p.

BUCKUP, P. A.; REIS, R. E. Characidim Genus Characidium (Telostei, Characiformes) in Southern Brazil, with Description of Three New Species. Copeia, v. 1997, n. 3, p. 531548, 1997.

CASATTI, L. Fish assemblage structure in a first order stream, southeastern Brazil: longitudinal distribution, seasonality, and microhabitat diversity. Biota Neotropica, v. 5, n. 1, p. 1-9, 2005. https://doi.org/10.1590/S1676-06032005000100009

CASATTI, L.; TERESA, F. B.; GONÇALVES-SOUZA, T.; BESSA, E.; MANZOTTI, A. R.; GONÇALVES, C. S.; ZENI, J. O. From forests to cattail: how does the riparian zone influence stream fish? Neotropical Ichthyology, v. 10, n. 1, p. 205-214, 2012. https://doi.org/10.1590/S1679-62252012000100020

CASATTI, L.; TERESA, F. B.; ZENI, J. O.; RIBEIRO, M. D.; BREJÃO, G. L.; CENEVIVABASTOS, M. More of the same: high functional redundancy in stream fish assemblages from tropical agroecosystems. Environmental Management, v 55, p. 1300-1314, 2015.

CORREA, S. B.; WINEMILLER, K. O. Flooding, fruiting phenology and resource partitioning among fishes in the Amazon. Ecology, v. 95, p. 210-224, 2014.

CRAMPTON, W. G. R. Gymnotiform fish: An important component of Amazonian floodplain fish communities. Journal of Fish Biology, v. 48, n. 1, p. 298-301, 1996. https://doi.org/10.1111/j.1095-8649.1996.tb01122.x

CROOK, D. A.; ROBERTSON, A. I. Relationships between riverine fish and woody debris: implications for lowland rivers. Marine \& Freshwater Research, v. 50, p. 942-953, 1999. https://doi.org/10.1071/MF99072

DAEE. Banco de Dados Hidrológicos. 2017. Available at: htttp://www.hidrologia.daee.sp.gov.br/. Access: 22 Aug. 2017.

DEVIDE, A. C. P.; CASTRO, C. M.; RIBEIRO, R. L. D.; ABBOUD, A. C. S.; PEREIRA, M. G.; RUMJANEK, N. G. História Ambiental do Vale do Paraíba Paulista, Brasil. Revista Biociências, v. 20, n. 1, p. 12-29, 2014.

ESTEVES, F. A. Fundamentos de limnologia. 2. ed. Rio de Janeiro: Interciência, 1998. 601 p.

FERREIRA, C. P.; CASATTI, L. Influência da estrutura do habitat sobre a ictiofauna de um riacho em uma micro-bacia de pastagem, São Paulo, Brasil. Revista Brasileira de Zoologia, v. 23, n. 3, p. 642-651, 2006.

FERREIRA, F. C.; SILVA, A. T.; GONÇALVES, C. S.; PETRERE JR., M. Disentangling the influences of habitat structure and limnological predictors on stream fish communities of a coastal basin, southeastern Brazil. Neotropical Ichthyology, v. 12, n. 1, p. 177-186, 2014. https://doi.org/10.1590/S1679-62252014000100019

FIGUEIREDO, R. O.; OVALLE, A. R. C.; REZENDE, C. E.; MARTINELLI, L. A. Carbon and Nitrogen in the Lower Basin of the Paraíba do Sul River, Southeastern Brazil: Element fluxes and biogeochemical processes. Revista Ambiente \& Água, v. 6, n. 2, p. 7-37, 2011. http://dx.doi.org/10.4136/ambi-agua.183 
FREITAS JUNIOR, G.; MARSON, A. A. Estudo comparado de biogeografia - caracterização da vegetação do Vale do Paraíba paulista nos anos de 1817 e 2007. In: SEMINÁRIO DE RECURSOS HÍDRICOS DA BACIA HIDROGRÁFICA DO PARAÍBA DO SUL, 1., 2007. Anais[...] Taubaté: IPABHI, 2007. p. 107-114.

FITZGERALD, D. B.; WINEMILLER, K. O.; SABAJ-PEREZ, M. H.; SOUSA, L. M. Seasonal changes in the assembly mechanisms structuring tropical fish communities. Ecology, v. 98, n. 1, p. 21-31, 2017. https://doi.org/10.1002/ecy.1616

GARUTTI, V. Distribuição longitudinal da ictiofauna em um córrego da região noroeste do Estado de São Paulo, bacia do Rio Paraná. Revista Brasileira de Biologia, v. 48, p. 747 759, 1998.

GILlER, P. S.; MALMQVIST, B. The Biology of Streams and Rivers. Oxford: Oxford University Press, 1998. 304 p.

GOMES, V. J. C.; FREITAS, P. T. A.; ASP, N. E. Dynamics and seasonality of the middle sector of a macrotidal estuaries. Journal of Coastal Research, Special Issue, p. 11401145, 2013. https://doi.org/10.2112/SI65-193.1

GONÇALVES, C. S.; BRAGA, F. M. S. Changes in ichthyofauna composition along a gradient from clearwaters to blackwaters in coastal streams of Atlantic forest (southeastern Brazil) in relation to environmental variables. Neotropical Ichthyology, v. 10, p. 675-684, 2012. https://doi.org/10.1590/S1679-62252012000300022

GONÇALVES, C. S.; BRAGA, F. M.; CASATTI, L. Trophic structure of coastal freshwater stream fishes from an Atlantic rainforest: evidence of the importance of protected and forest-covered areas to fish diet. Environmental Biology of Fishes, v. 2018, p. 933-948, 2018. https://doi.org/10.1007/s10641-018-0749-8

HONORIO, J. R.; MARTINS, I. A. Ichthyofauna of the Una river in the Paraíba do Sul Paulista River Valley, Southeastern of Brazil. Biota Neotropica, v. 18, n 4, p. 1-8, 2018. https://doi.org/10.1590/10.1590/1676-0611-bn-2018-0528

HUTCHESON, K. A test for comparing diversities based on the shannon formula. Journal of Theoretical Biology, v. 29, n. 1, p. 151-154, 1970. https://dx.doi/10.1016/00225193(70)90124-4

JARDINE, T. D.; BOND, N. R.; BURFORD, M. A.; KENNARD, M. J.; WARD, D. P.; BAYLISS, P.; DAVIES, P. M.; DOUGLAS, M. M.; HAMILTON, S. K.; MELACK, J. M.; NAIMAN, R. J.; PETTIT, N. E.; PUSEY, B. J.; WARFE, D. M.; BUNN, S. E. Does flood rhythm drive ecosystem responses in tropical riverscapes? Ecology, v. 96, v. 3, p. 684-692, 2015. https://doi.org/10.1890/14-0991.1

JUNK, W. J.; BAYLEY, P. B.; SPARKS, R. E. The flood pulse concept in river-floodplain systems. In: INTERNATIONAL LARGE RIVER SYMPOSIUM, 1989, Honey Harbour, Ontario. Proceedings[...] Ottawa: Canadian Special Publication of Fisheries and Aquatic Sciences, 1989. p. 110-127.

KOVALENKO, K. E.; THOMAZ, S. M.; WARFE, D. M. Habitat complexity: approaches and future directions. Hydrobiologia, v. 685, p. 1-17, 2012. 
KRUPEK, R. A.; BRANCO, C. C. Z.; PERES, C. K. Variação sazonal de alguns parâmetros físicos e químicos em três rios pertencentes a uma bacia de drenagem na região centrosul do Estado do Paraná, Sul do Brasil. Acta Scientiarum. Biological Sciences, v. 30, n. 4, p. 431-438, 2008. https://dx.doi.org/10.4025/actascibiolsci.v30i4.5873

LANGEANI, F.; CASATTI, L.; GAMEIRO, H. S.; CARMO, A. B.; ROSSAFERES, D. C. Riffle and pool fish communities in a large stream of southeastern Brazil. Neotropical Ichthyology, v. 3, n. 2, p. 305-311, 2005. http://dx.doi.org/10.1590/S167962252005000200009

LEITÃO, R. P.; BUCKUP, P. A. A New Species of Characidium (Characiformes: Crenuchidae) from Coastal Basins of Serra do Mar, Southeastern Brazil. Copeia, v. 1, n. 1, p. 14-22, 2014. https://doi.org/10.1643/CI-12-137

LEITÃO, R. P.; CARAMASCHI, E. P.; ZUANON, J. Following food clouds: association between a minute loricariid and a characidiin species in an Atlantic Forest stream, Southeastern Brazil. Neotropical Ichthyology, v. 5, n. 3, p. 307-310, 2007. http://dx.doi.org/10.1590/S1679-62252007000300011

LEITÃO, R. P.; SÁNCHEZ-BOTERO, J. I.; KASPER, D.; TRIVÉRIO-CARDOSO, V.; ARAÚJO, C. M.; ZUANON, J.; CARAMASCHI, E. P. Microhabitat segregation and fine ecomorphological dissimilarity between two closely phylogenetically related grazer fishes in an Atlantic Forest stream, Brazil. Environmental Biology of Fishes, v. 15, n. 98, p. 2009-2019, 2015.

LOWE-McCONNELL, R. H. Ecological studies in tropical fish communities. Cambridge: Cambridge University Press. 1987. 382 p.

LUCENA, C. A.; SOARES, H. G. Review of species of the Astyanax bimaculatus "caudal peduncle spot" subgroup sensu Garutti \& Langeani (Characiformes, Characidae) from the rio La Plata and rio São Francisco drainages and coastal systems of southern Brazil and Uruguay. Zootaxa, v. 4071, n. 1, p. 101-125, 2016. https://www.researchgate.net/deref/http\%3A\%2F\%2Fdx.doi.org\%2F10.11646\%2Fzoot axa.4072.1.5

MAGURRAN, A. E.; MCGILL, B. J. Biological Diversity: Frontiers in measurement and assessment 1. ed. Oxford, Reino Unido: Oxford University Press, 2011. 345 p.

MAZZONI, R.; J. LOBÓN-CERVIÁ. Longitudinal structure, density and production rates of a tropical stream fish assemblage: the river Ubatiba in the Serrado Mar, southeast Brazil. Ecography, v. 23, p. 502-588, 2000. https://doi.org/10.1111/j.16000587.2000.tb00178.x

PERES-NETO, P. R.; LEGENDRE, P.; BORCARD, D. Variation partitioning of species data matrices: estimation and comparison of fractions. Ecology, v. 87, p. 2614-2625, 2006. https://doi.org/10.1890/0012-9658(2006)87[2614:VPOSDM]2.0.CO;2

POFF, N. L. Landscape filters and species traits: towards mechanistic understanding and prediction in stream ecology. Journal of the North American Benthological Society, v. 16, n. 2, p. 391-409, 1997.

POWER, M. E.; PARKER, M. S.; DIETRICH, W. E. Seasonal reassembly of river food web: floods, droughts, and impacts of fish. Ecological Monographs, v. 78, n. 2, p. 263-282, 2008. 
PRADO, J. B.; ABREU, M. M. Aspectos Geográficos do Vale do Paraíba e Município de Taubaté. Taubaté: Center Gráfica e Editora, 1995. 280 p. (Coleção Taubateana, n. 14).

PUSEY, B. J.; ARTHINGTON, A. H. Importance of the riparian zone to the conservation and management of freshwater fish: a review. Marine \& Freshwater Research, v. 54, p. 1$16,2003$.

REIS, R. E. Family Callichthyidae. In: REIS, R. E.; KULLANDER, S. O.; FERRARIS, C. J. Checklist of the freshwater fishes of South and Central America. Porto Alegre: Edipucrs, 2003. p. 291-309.

REZENDE, C. F.; MORAES, M.; MANNA, L. R.; LEITÃO, R. P.; CARAMASCHI, E. P.; MAZZONI, R. Mesohabitat indicator species in a coastal stream of the Atlantic rainforest, Rio de Janeiro-Brazil. Revista de Biologia Tropical, v. 58, n. 4, p. 1479-1487, 2010 .

SABO, J.; RUHI, A.; HOLTGRIEVE, G.; ElliOTT, V.; ARIAS, M.; NGOR, P. B.; RÄSÄNEN, T.; NAM, S. Designing river flows to improve food security futures in the lower Mekong basin. Science, v. 358, n. 1270, p. 1-12, 2017. https://dx.doi.org/10.1126/science.aao1053

SCHLOSSER, I. J. Fish community structure and function along two habitat gradients in a headwater stream. Ecological Monographs, v. 52, p. 395-414, 1982. https://doi.org/10.2307/2937352

SOUZA, C. F.; BACICURINSKI, I.; SILVA, E. F. F. Avaliação da qualidade da água do rio Paraíba do Sul no município de Taubaté-SP. Revista Biociências, v. 16, n. 1, p. 16-23, 2010.

TARGA, M. S. Estudo Hidrológico da Bacia do Rio Una: Subsídios para estabelecimento de plano de macrodrenagem no Vale do Paraíba do Sul - SP. Taubaté: UNITAU, 2009. p. $1-14$.

TEIXEIRA, T. P.; TERRA, B. F.; ESTILANO, E. O.; GARCIA, D.; PINTO, B. C. T.; ARAÚJO, F. G. Distribuição da ictiofauna em locais impactados no rio Paraíba do Sul. Seropédica, v. 24, n. 2, p. 167-174, 2004.

VANNOTE, R. L.; MINSHALL, G. W.; CUMMINS, K. W.; SEDDEL, J. R.; CUSHING, C. E. The river continuum concept. Canadian Journal of Fishes and Aquatic Sciences, v. 37, p. 130-137, 1980. https://doi.org/10.1139/f80-017 